\title{
The paradigmatic field of usage of the theoretical category of pluriactivity in Brazil
}

\begin{abstract}
Márcia Danielly Cavalcanti Silva ${ }^{1 *}$ (D) Ana Louise De Carvalho Fiúza ${ }^{1}$ Neide Maria de Almeida Pinto ${ }^{2}$
${ }^{1}$ Departamento de Economia Rural, Programa de Pós-Graduação em Extensão Rural, Universidade Federal de Viçosa (UFV), Viçosa, MG, Brasil. E-mail: marcia_dany11@yahoo.com.br. "Corresponding author.

${ }^{2}$ Departamento de Economia Doméstica, Universidade Federal de Viçosa (UFV),Viçosa, MG, Brasil.

ABSTRACT: The lack of interpretive convergence around an analytical category or concept generates a field of disputes around the understanding of a certain phenomenon. This is also the case with "pluriactivity", on which there remain interpretive divergences derived from its conception. This research aims to identify the interpretive tendencies that are gaining traction in Brazil. For that, the research used as a database the Brazilian Digital Library of Theses and Dissertations (BDTD - "Biblioteca Digital Brasileira de Teses e Dissertações"), since this type of database compiles and updates the state of the art on the subject. The research universe consisted of 115 dissertations and theses were systematized and analyzed using IRAMUTEQ software. Results showed that the development of theses and dissertations studying the theme of pluriactivity has remained as a current research topic. A higher incidence was noted more in the Southern and Southeastern universities of the country, where the dynamics between the three sectors of the economy favor the possibility of combining agricultural and non-agricultural activities. The conclusions of the research pointed to the coexistence of two different conceptions regarding pluriactivity: one that characterizes it as a strategy of reproduction and survival; and another that associates it with the diversification of the labor market at the regional level, which would allow the farmers' family members to diversify the family income and increase the possibilities of investment in the activities developed in the rural property.

Key words: pluriactivity, reproduction strategy, survival strategy, labor market, state of the art.
\end{abstract}

O campo paradigmático de emprego da categoria teórica pluriatividade no Brasil

RESUMO: A falta de convergência interpretativa em torno de uma categoria analítica ou conceito gera um campo de disputas em torno da compreensão de um determinado fenômeno. Este é o caso da "pluriatividade", sobre a qual ainda pairam divergências interpretativas derivadas da sua concepção. O presente artigo teve como objetivo identificar as tendências interpretativas que estão ganhando hegemonia no Brasil. Para tanto, a pesquisa utilizou como base de dados a Biblioteca Digital Brasileira de Teses e Dissertações, visto que este tipo de texto cientifico congrega e atualiza o estado da arte sobre a temática. O universo da pesquisa constituiu-se de 115 dissertações e teses que foram sistematizadas e analisadas no software IRAMUTEQ. Os resultados mostraram que o desenvolvimento de teses e dissertações com a temática da pluriatividade tem-se mantido como um tema atual de pesquisa, tendo maior incidência nas Universidades do Sul e do Sudeste do pais, onde a dinâmica entre os três setores da economia, favorece a possibilidade de combinação de atividades agrícolas e não agrícolas. As conclusões da pesquisa apontaram para a coexistência de duas diferentes concepções relativas à pluriatividade: uma que a caracteriza como uma estratégia de reprodução e sobrevivência; e outra que associa à diversificação do mercado de trabalho em nivel regional, o qual oportunizaria aos membros das famílias de agricultores à diversificação da renda familiar e ampliação das possibilidades de investimento nas atividades desenvolvidas na propriedade rural.

Palavras-chave: pluriatividade, estratégia de reprodução, estratégia de sobrevivência, mercado de trabalho, estado da arte.

\section{INTRODUCTION}

The conception of pluriactivity gained notoriety in Brazil as a way of emphasizing the phenomenon of coexistence of agricultural and nonagricultural activities in family production units. The academic literature of the 1990s evidenced the phenomenon related to the growth of farmers' family members who lived in the countryside but performed non-agricultural activities (GRAZIANO DA SILVA 1999, MACHADO; CASALINHO, 2010).

Thus, in the literature, the use of terms such as "part-time farming", "dual activity" and "pluriactivity" was used to describe the phenomenon of combining agricultural and non-agricultural activities. However, there was no concern in analyzing whether it would be coherent, theoretically, to conceptualize by a single term phenomenon 
that could be driven by completely different rationalities and socioeconomic strategies. In this way, this research aimed to carry out a survey of the meanings and descriptions associated to the category "pluriactivity", since it has been used in Brazil. To achieve such goal, it was used as a methodological strategy, to analyze the theses and dissertations made available in the Brazilian Digital Library of Theses and Dissertations (BDTD), in order to gather and update the academic debate on the subject at the national level, particularly in the case of $\mathrm{PhD}$ theses. However, even if the central aim of this research was to understand the applicability of the concept of "pluriactivity" to the Brazilian reality, it also mapped the main international theoretical influences cited by the Brazilian researchers.

The category of "pluriactivity" gained an explanatory strength in Brazil during the 1990s when it described the growth of the "Ocupações Rurais Não Agrícolas-ORNAs" (Non-Agricultural Rural Occupations), which pointed to the diversity of the labor market in the Brazilian rural economy (GRAZIANO DA SILVA, 1999; MATTEI, 1999; DEL GROSSI, 1999). The new productive activities carried out by the farmers' family members, concomitant with the integration of consumer society, characterized some of the changes described by Brazilian researchers that pointed to the dilution of the boundaries between rural and urban contexts in Brazil. The finding of this phenomenon allowed the growth of the pluriactivity category in the research carried out by different researchers, such as CARNEIRO (1998), KAGEYAMA (1998), SCHNEIDER (2003), NASCIMENTO (2005), WANDERLEY (2009), and ESCHER (2014), among others.

Initially, the conceptions of pluriactivity at the international level were mapped, rescuing the interpretative syntheses already being elaborated by Brazilian authors about the conceptions of the analytical category "pluriactivity" in the international literature. Such a theoretical mapping allowed a perception of the explanatory currents that influenced the Brazilian authors. In the following section, we presented the conception of the Brazilian authors who introduced and popularized the term "pluriactivity" at the national level. We presented the theoretical perspectives of the authors who first explored the subject of pluriactivity in Brazil, which became a reference for researchers who were in the period of scientific training, doing their dissertations and $\mathrm{PhD}$ theses. The following topic is related to the analysis of content made from the use of IRAMUTEQ software, which was used in the analysis of the
115 theses and dissertations that had as focus of approach the category pluriactivity, pointing out its main analyzes, obtained from the application of the software. Finally, the conclusions will present the interpretive tendencies that have been consolidated by the Brazilian research about pluriactivity.

\section{Conceptions of pluriactivity in the international literature}

Among the authors who first published the term "pluriactivity", FULLER (1990) stands out. The author presented a discussion on the focal points of the report on the Arkleton Trust Project, published in 1987, which was drawn from the experience of 12 European countries. From this study, the pluriactivity of "agricultural families" began to be highlighted because of macroeconomic transformations.

The family; therefore, was taken as the unit of analysis of the phenomenon characterized as "pluriactivity". According to SCHNEIDER (1994), this question of taking the "family" or the "production unit" as a unit of analysis was already present in the debate between the "Neokautskyists" and the "Chayanovists". The "Neokautskyists" defended the perspective of the development of capitalism in agriculture, stating that it would provoke the unification of the rural and urban labor markets, taking as a unit of analysis the "unit of production". The "Chayanovists"; conversely, placed greater emphasis on the working family.

FULLER $(1984,1990)$ reviewed the main works of the international literature and pointed out that the term part-time farming arose in order to differentiate farmers who produce for subsistence as opposed to those who produce on a full-time basis for market. The author then proposed replacing the term part-time farming with multiple job holding farm household (MJHFH), proposing a reorientation of the unit of analysis of "working time dedicated to agriculture" for the analysis of the farmers' families, taking into consideration their composition, decisionmaking and the will/interest of the individuals (FULLER, 1990). However, this approach based on the multiple job holding perspective was replaced by the notion of pluriactivity, interpreted as a phenomenon that would combine multiple forms of work and income by those living in agricultural units. The notion of pluriactivity was thus introduced in an academic context, considering the multiple sources of income of the families of farmers inserted in new local markets (FULLER, 1990).

Additionally, in France, discussions on the category of pluriactivity emerged when 
highlighting the distinction of "status" of farmers who were engaged in full-time agricultural activities compared to part-time farmers. Such antagonism was expressed in the perspective of the "false farmer", stigmatized as a function of developing other activities than the agricultural ones. CAMPAGNE et al., (1990) emphasized; however, that; although, pluriactivity was negatively characterized, this perception was changing due to its positivity for the rural development of the French regions. This feature of the French literature is also pointed out by CARNEIRO (1998), which highlighted the fact that non-agricultural activities are becoming an economic and social alternative for families living in the countryside. Thus, in the French case, the key element brought about using the term "pluriactivity" was the displacement of its focus from the analysis of the productive unit to the familiar strategies of social reproduction.

In other more recent researches on the development of pluriactivity, NIEMELA and HAKKINE (2015), studying the phenomenon in Finland, also interpreted pluriactivity as a strategic orientation for farmers' families who used family income diversification as an alternative to property growth.

However, the characterization of pluriactivity as a phenomenon related to the fight against rural poverty also appears in the international literature as another way of characterizing the phenomenon of pluriactivity. BOUCHAKOUR and BEDRANI (2015), studying the phenomenon in Algeria, pointed out that pluriactivity emerges as an alternative to complementing low income, analyzing the peculiarity of the country which has suffered in recent decades with problems related to terrorism and the effects of disease. BLAD (2010) points out in his paper on Poland that pluriactivity is a survival strategy, with a diversification of family income sources seem as a strategy of social reproduction, which becomes possible through the development of the economy. LOUGHREY et al. (2013) make an econometric analysis of the main characteristics of pluriactivity in Ireland and pointed to the existence of two forms of pluriactivity in the country: the first one is related to the agricultural diversification carried out within the property; and the second one about the multiple activities outside the property through multiple jobs. For the authors, the main impact observed in the research was the confirmation of the previous literature, which demonstrated that the properties that developed multiple jobs tended to reduce successors in the property. In the case of Ireland, the authors pointed out that pluriactivity is a short-term survival strategy and; although, it may extend agricultural activities, it does not guarantee the long-term sustainability of agriculture. And finally, CHASE (2010) performed an analysis of two Brazilian agrarian institutions - powerful actors in the discourse of agrarian reform. The research criticizes the two agrarian institutions because they did not understand pluriactivity in the context of the country as their agricultural policies did not see a means for survival and rural subsistence. Thus, the author sees that income diversification in rural areas is often compromised because official agrarian agencies do not recognize non-local or non-agrarian activities as part of rural livelihoods.

\section{The introductory conceptions of the pluriactivity category in Brazil}

In this section we presented the theoretical perspectives of Brazilian authors who first explored and popularized the topic of pluriactivity in Brazil. These authors became reference points for the researchers who were in the period of scientific formation, carrying out their dissertations and theses. GRAZIANO DA SILVA (1996, 1997, 2001,) was one of the first Brazilian authors to approach the analytical category pluriactivity; although, without using it directly. In his research " $O$ novo rural Brasileiro", in 1997, the author used the category "part-time farmer" to point out the increasing nonagricultural activities carried out by rural families in the state of São Paulo. Through the "RURBANO" project, initiated in 1997, the author guided the development of the methodologies to quantify the expansion of non-agricultural activities in rural areas. The project was conducted based on the microdata of the "Pesquisa Nacional por Amostra de Domicilios- PNAD" (National Survey by Household Sample), made available by the Instituto Brasileiro de Geografia e Estatística-IBGE (Brazilian Institute of Geography and Statistics) in the years 1992 to 1999 and 2001. In, GRAZIANO DA SILVA (1999) used the category of pluriactivity interpreting it as the combination of agricultural and nonagricultural activities developed by the members of a family unit. According to the author, pluriactivity would constitute a typical manifestation of the Brazilian "new rural" (GRAZIANO DA SILVA and CAMPANHOLA, 2000; GRAZIANO DA SILVA and DEL GROSSI, 2001).

$$
\text { Concurrently, CARNEIRO (1998) }
$$
corroborate with the ideas GRAZIANO used the pluriactivity category in his doctoral thesis, "Camponeses, agricultores e pluriatividade", carried out in the French Alps, highlighting the role of the 
family and the proximity of the relationships between the countryside and the city in the understanding of the pluriactivity phenomenon. In her study, the author highlighted the facilitation of new economic activities in the countryside, such as winter tourism, characterizing it as a new reproduction strategy for the families of farmers, which enabled them to access complementary sources of income and/ or alternatives for ensuring permanence in the countryside. The implementation of a microsociological analysis allowed the author to perceive the strategies implemented by the family in the surroundings of the multiple occupations performed by its members in favor of the reproduction of the family productive unit.

For CARNEIRO (1998), pluriactivity would correspond to the combination of agricultural and non-agricultural activities developed by the same family inserted in a specific socioeconomic context, marked by economic diversification and the dynamism of the regional labor market. Thus, pluriactivity would develop through the approximation of agricultural labor markets and the secondary and tertiary sectors of the economy (CARNEIRO 2006, 2009, 2016).

CARNEIRO (1998) inspired a new interpretive possibility of the phenomenon of pluriactivity, turning it into the perception of pluriactivity as a logic of reproduction that would be removed from the phenomenon that characterized the social type of "settler/farmer-worker". For the author, pluriactivity would be related to the specificity of a more dynamic economic fabric, both locally and regionally, that would allow the greater fluidity of goods and people between the countryside and the surrounding areas. The possibility of rapid displacement of some members of farmer families to carry out non-agricultural research would differ from that of the "farmer/peasant/settler-worker" immersion context, for whom the possibilities of displacement and exercise of a non-agricultural activity relegated the agriculture to a second level.

Another author who became a reference point for studies on pluriactivity was KAGEYAMA (1998), with her research entitled, "Pluriatividade e ruralidade: aspectos metodológicos. The author used data from 1995 from the PNAD to compare the characteristics of pluriactive and monoactive agricultural households, covering 572 municipalities in the state of São Paulo. In her analysis, the author used an aggregation of households based on social and economic indicators, ranging from "too poor rural" to dense urban. For the author, pluriactivity would have different meanings considering on the analytical level investigated. At the micro level, the family would be the unit of analysis, and at the macro level the unit of analysis would be the labor market. Thus, pluriactivity would have different meanings according to the stage of development of the family agricultural economy and its context. In another research published (KAGEYAMA, 2008), deepens the emphasis on the macroeconomic dimension of the phenomenon of pluriactivity, pointing out that this would be related to the process of interiorization of the industries, which promoted the intersectoralization of the economy in some Brazilian regions, providing the growing interweaving of agricultural, industrial, and service sector activities in the post-Fordist period to the small and medium-sized municipalities.

DEL GROSSI (1999), in his doctoral thesis entitled "Evolução das Ocupações não agrícolas no meio rural Brasileiro 1981-1995," almost synonymized the category of pluriactivity of "part-time farming", highlighting a difference between these two categories: while the category of "part-time farming" would be linked to the agricultural establishment, the analytical category "pluriactivity" would take the family as a unit of analysis, clearly revealing an influence of Chayanovist theories. According to DEL GROSSI (1999), agricultural modernization has brought a reduction in agricultural employment.

In the conclusions of his research, the author pointed out that pluriactivity was not characterized as an isolated phenomenon, but, on the contrary, would manifest itself in all rural areas, especially in small and medium-sized municipalities.

SCHNEIDER(1999), can beconsidered one of the authors most responsible for the popularization of the pluriactivity category in Brazil. In his thesis entitled "Agricultura Familiar e Pluriatividade", published in 2003, the author conceptualizes pluriactivity as a strategy of combining agricultural and non-agricultural activities, marked by different combinations, that would aim the social and economic development of families from rural areas. According to SCHNEIDER (2003), pluriactivity as a combination of agricultural, para-agricultural and non-agricultural activities would not necessarily mark the existence of a new phenomenon, as for CARNEIRO (1998, 2006, 2009), for whom the socioeconomic context of proximity between the countryside and the city would give a differentiated connotation to the relations between agricultural and non-agricultural activities. SCHNEIDER (2006) explained his understanding of pluriactivity through five typologies - two which are related to contemporary characteristics and the other three with longer-lived phenomena, that had already 
existed for a long time in peasant societies. In this list of contemporary typologies, it would include intersectoral pluriactivity, arising from the articulation of the agricultural sector with industry, commerce and service, typical of the post-Fordist period; also, the agrarian-based pluriactivity that would occur within the agricultural sector due to the outsourcing of various phases of the production process. The other three types, the para-agricultural pluriactivity, marked by the processing or transformation of plant products, animals or beverages for the purpose of selling the surplus; the pluriactivity linked to informal work, which would be characterized by the sale of labor in temporary or sporadic jobs; and traditional or peasant pluriactivity characterized by the search for self-sustenance and low external dependence; all these three types of activities would have a more timeless character. Thus, according to SCHNEIDER (2003), pluriactivity would essentially be the combination of agricultural activities with para-agricultural or nonagricultural activities, which would incorporate the nuances of their historical context.

MATTEI (1999) is another important point of reference in the study of pluriactivity in Brazil. In his doctoral thesis entitled "Pluriatividade $e$ Desenvolvimento Rural no Estado de Santa Catarina", the author analyzed changes in the dynamics of rural labor in the state of Santa Catarina, from the evolution of agricultural and non-agricultural occupations in the period between 1981 and 1997.

The author characterized the phenomenon of pluriactivity as revealing the heterogeneity of the economic activities carried out by the families living in the countryside, in view of the socioeconomic environment into which they are inserted. The author emphasizes in his study that pluriactivity was gradually ceased being interpreted as a strategy of transient survival, coming to be seen instead as an alternative of income complementation of a stable and permanent character. Pluriactivity is thus understood by the author as a result of the "interrelations between the dynamics of families, farms and the socioeconomic context where families and farming units are inserted" (MATTEI, 1999, p.13).

SACCO DOS ANJOS (2003) is another author who leverages studies on pluriactivity in Brazil, with his doctoral thesis "Agricultura Familiar, Pluriactividad y Desarrollo Rural en el Sur de Brasil" (original version, translated as a book in 2003), in which the author presents three perspectives present in the literature on pluriactivity: i) he focused on the phenomenon of pluriactivity from a macrostructural view, focusing the analysis on the changes and transformations of social and economic structures considering them as fundamental in determining the appearance of the phenomenon; ii) It has a microstructural character, seeking to understand the phenomenon of pluriactivity, taking as its focus the changes and transformations of social and economic structures at the local level; and finally iii) he groups the two previous perspectives to explain the phenomenon of pluriactivity. For SACCO DOS ANJOS (2003), pluriactivity would point to the emergence of the combination of agricultural and non-agricultural activities in the rural environment, in a context in which farmers' families were traditionally accustomed to strictly agricultural activities, but as a result of the economic changes they can then move on to other activities. Such activities, as social reproduction strategies, included the sale of the family labor force, the provision of services or the development of internal initiatives such as rural tourism, craftsmanship, diversification in production, or even through small improvements of its products (SACCO DOS ANJOS, 2003). According to the author, pluriactivity would not refer to something new, but to the combinatory practices of agricultural and non-agricultural activities existing in earlier times.

In his $\mathrm{PhD}$ thesis entitled "Pluriatividade, Pobreza e Políticas Publicas", NASCIMENTO (2005, 2009) carried out a study on pluriactivity, presenting a comparative study with data from the PNAD from 1992-1999 and 2001-2005, referring to the southern and northeastern macro regions of Brazil. In this research, the author pointed out that pluriactivity was increasing in Brazil in poorer areas and regions such as the Northeast, arguing that the dynamics of pluriactivity in a given region was related to the economically active population in agriculture rather than to the characteristics of the local economy. In contrast to NASCIMENTO $(2005,2009)$, TEIXEIRA (2009) in his case study on the mountainous region of Rio de Janeiro, Nova Friburgo municipality, "Novos contornos ocupacionais no meio rural fluminense: um estudo sobre a pluriatividade entre agricultores familiars", presented the life and work trajectory of the families surveyed, noting that the pluriactivity in that region constituted a form of stable and structural work that allowed the maintenance of families, due to the improvement of income and quality of life.

In more recent research, ESCHER et al. (2014) concluded that pluriactivity occurred due to factors internal to the family unit, but also, due to the external economic context. Hence, they argued that there is no single type of pluriactivity. When analyzing the 2006 Agricultural Census 
of the South and Northeast regions, the authors verified a considerable number of pluriactive establishments classified as non-family agriculture. This is based on the justification that aggregate data are only estimates; and that although, statistically significant, the unit of analysis of this research was constituted in agricultural establishments. The most significant result of this research was the possibility of approaching the existence of a portion of family farmers who, due to their pluriactivity, are classified erroneously, being excluded from official statistics and from public policies aimed at family agriculture.

Table 1 presents the main changes that occurred during the studies of pluriactivity in Brazil, pointing out the authors, the region studied, and their main considerations obtained in the research. However, the table does not show the early research that emerged in the period prior to the 1990s nor the studies conducted in the period between 1994 and 1995, which adopted the term "farmer/peasant/settlerworker" so they were not presented. Subsequently, the expressions "part-time agriculture" and pluriactivity were inserted into the surveys.

\section{Methodology for data collection and analysis}

In summary, it is noted in the scientific literature that studies on pluriactivity can reach very different conclusions about the phenomenon, according to the way in which they conceive it theoretically. The main interpretive controversies around the analytical category "pluriactivity" can be summarized in the following points: i) "Pluriactivity" would be a new phenomenon, marked by economic conditions linked to diffused industrialization and the growing proximity of relations and exchanges between the countryside and the city, being typical of certain regions (CARNEIRO, 1998; GRAZIANO, 1999; MATTEI, 1999, KAGEYAMA, 2008); or it could exist in a generalized way in any region, becoming a timeless phenomenon that would have always existed in other historical contexts, under a different nomenclature, such as "part-time farming" or "double activity" among others (SCHNEIDER, 2003; SACCO DOS ANJOS, 2003); ii) The unit of analysis characteristic of the phenomenon of pluriactivity would be the family (CARNEIRO, 1998) or the productive unit (SCHNEIDER, 2003); iii) The pluriactivity would allow the strengthening of the family productive unit (CARNEIRO, 1998) or would be characterized as a phenomenon associated with the fight against poverty and the quest for survival (NASCIMENTO, 2005). It can be seen from table 1 that the studies using the analytical category "pluriactivity" began to spread more intensely after

Table 1 - Historical evolution of the main studies of pluriactivity in Brazil.

\begin{tabular}{|c|c|c|}
\hline Author/Year & Studied Region & Main considerations \\
\hline Graziano Silva (1996) & São Paulo (state of Brazil) & $\begin{array}{l}\text { It highlighted the growing participation of ORNAS (Ocupações Rurais } \\
\text { Não-Agricolas) by members of rural families and the reduction of } \\
\text { agricultural jobs, pointing to the phenomenon of "pluriactive families". }\end{array}$ \\
\hline Del Grossi (1999) & South- Paraná (state of Brazil) & $\begin{array}{l}\text { It pointed out that there is an expansion of employment in the service } \\
\text { and trade sectors to the detriment of agricultural activities among the } \\
\text { population residing in rural households. }\end{array}$ \\
\hline Kageyama (1998) & São Paulo (state of Brazil) & $\begin{array}{l}\text { It used the PNAD data to compare the characteristics of pluriactive and } \\
\text { monoactive agricultural households in the Sao Paulo State. Unit analysis } \\
\text { at the micro level is the family and at the macroeconomic level is the } \\
\text { labor market. }\end{array}$ \\
\hline Mattei (1999) & Santa Catarina (state of Brazil) & $\begin{array}{l}\text { It analyzed the changes taking place in the dynamics of rural work and } \\
\text { found that rural employment was no longer exclusively agricultural. } \\
\text { Family as unit of analysis }\end{array}$ \\
\hline $\begin{array}{l}\text { Campanhola; Silva e } \\
\text { Del Grossi (2001) }\end{array}$ & São Paulo (state of Brazil) & $\begin{array}{l}\text { They analyzed the ongoing transformations in the rural area of São } \\
\text { Paulo and observed that there was a reduction of rural exodus in the } \\
\text { interior municipalities in the } 1990 \text { s due to non-agricultural occupations. }\end{array}$ \\
\hline Schneider (2003) & $\begin{array}{l}\text { Rio Grande do Sul (state of } \\
\text { Brazil) }\end{array}$ & $\begin{array}{l}\text { The pluriactivity would be a phenomenon that presupposes the } \\
\text { combination of at least two activities, one of them being agricultural. } \\
\text { Unit of analysis as the family and the individual. }\end{array}$ \\
\hline $\begin{array}{l}\text { Sacco dos Anjos } \\
(2000,2003)\end{array}$ & Massaranduba-SC & $\begin{array}{l}\text { Pluriactivity as strategies for the reproduction of the family unit. With a } \\
\text { micro and macroeconomic analysis. }\end{array}$ \\
\hline
\end{tabular}

Source: Elaborated by the authors based on literature 2018 . 
the 1990s and that they were concentrating their research in the South and Southeast regions of the country, where the intersectoriality of the economy is evidenced with greater strength. Table 1 shows the strong influence of Chayanovist conceptions, highlighting the strength of family strategies for the characterization of pluriactivity.

In order to present the best research that uses the pluriactivity category, a survey of the main theses and dissertations were made available in the database of the BDTD with open access. Documents that are available were provided by the educational institutions of the Brazilian Graduate Programs, which are responsible for the veracity of the information. The database integrated a catalog of theses and dissertations at the national level and full content, with the metadata organized by title, author, abstract, and keywords. The search in the database was carried out adopting the following procedures: i) content mapping; ii) establishment of content inclusion and exclusion criteria; and iii) creation of the corpus for analysis in the IRAMUTEQ software.

In the first stage, the mapping was performed in June 2018 with a search on the database site, using for these purposes the search terms "pluriatividade" (Portuguese word) or "pluriactivity" (English translation of "pluriatividade"). The research used these two initial keywords without using filters. A total 128 theses and dissertations referring to the period from 1999 to 2017 were initially reported. For the second stage, the titles, abstracts and keywords of the 128 files were studied in order to verify the adequacy of the theme of the dissertation and/or thesis to the research objective. In this stage the inclusion and exclusion criteria were implemented. Duplicated files or those that were considered outside the subject matter were removed from the final count. After this, 115 dissertations and theses remained for analysis. Information such as title, authorship, educational institution, program and area of concentration, orientation, year, type of document (dissertation or $\mathrm{PhD}$ thesis), keywords and abstracts, were transcribed for Microsoft Word for the making of a corpus, which corresponded to the third stage of this research.

In this third stage, the formation of the corpus was performed from the transcription of the abstract of each dissertation or thesis in the Word document. In total, 115 fragments (abstracts) were transcribed for the creation of the corpus of this research. In order to conduct this data analysis, the software IRAMUTEQ (Interface de R pour les Analyses Multidimensionnelles de Textes et de Questionnaires) was used. IRAMUTEQ is a free software developed by RATINAUD (2009). It is possible to perform statistical analysis and different processing of transcribed verbal material. The software works in interface with software R to carry out multivariate analysis of texts (RATINAUD and MARCHAND, 2012).

According to the database provided by the BDTD, 115 theses and dissertations were found to compose the debate about scientific production referring to the meaning of the category of pluriactivity in the research carried out in Brazil. The data showed that the topic of pluriactivity experienced gradual growth from 1999, the year in which the first work made available by the database was identified (SCHNEIDER 2006 MACHADO and CASALINHO, 2010, ESCHER et al. 2014). Of the 115 documents found, 85 of them $(73 \%)$ corresponded to dissertations and 31 $(27 \%)$ to theses. Figure 1 shows the distribution of publications by period, in which pluriactivity refers to the family farmer that combines agricultural activities with non-agricultural activities as a way of complementing his family income and reproducing himself socially (ESCHER, et al, 2014; FARIAS, 2016; TERNOSKI, 2013).

Regarding the scientific production by educational institutions, 39 Higher Education Institutions were identified with publications related to pluriactivity - those being highlighted were located in the South (UFRGS, UFSC, UFSM, UFPeL, UFPR and UNIOESTE) and Southeast regions (UNICAMP, UNESP, UFV and UFU), which represented $65 \%$ of the institutions. This prominence of the studies relating to pluriactivity in the South and Southeast regions may be related to the fact that the intersectoriality of the economy at the local and microregional levels is more pronounced in these regions. Among the postgraduate programs identified in the analyzed research, a wide range of degrees were reported, including Geography, Rural Extension, Economic Sciences, Regional Development and Agribusiness.

The Hierarchical Descending Classification (HDC) analysis from the IRAMUTEQ software allowed us to identify the main words that appeared in the 115 dissertations and theses, grouping them into thematic classes, which are presented in the dendogram in figure 2. The words contained in each class point to the relation of the proximity of the meaning existing internally between them.

However, it is not only the words belonging to a class that indicate the proximity of meaning to each other, but also the classes themselves, in relation 


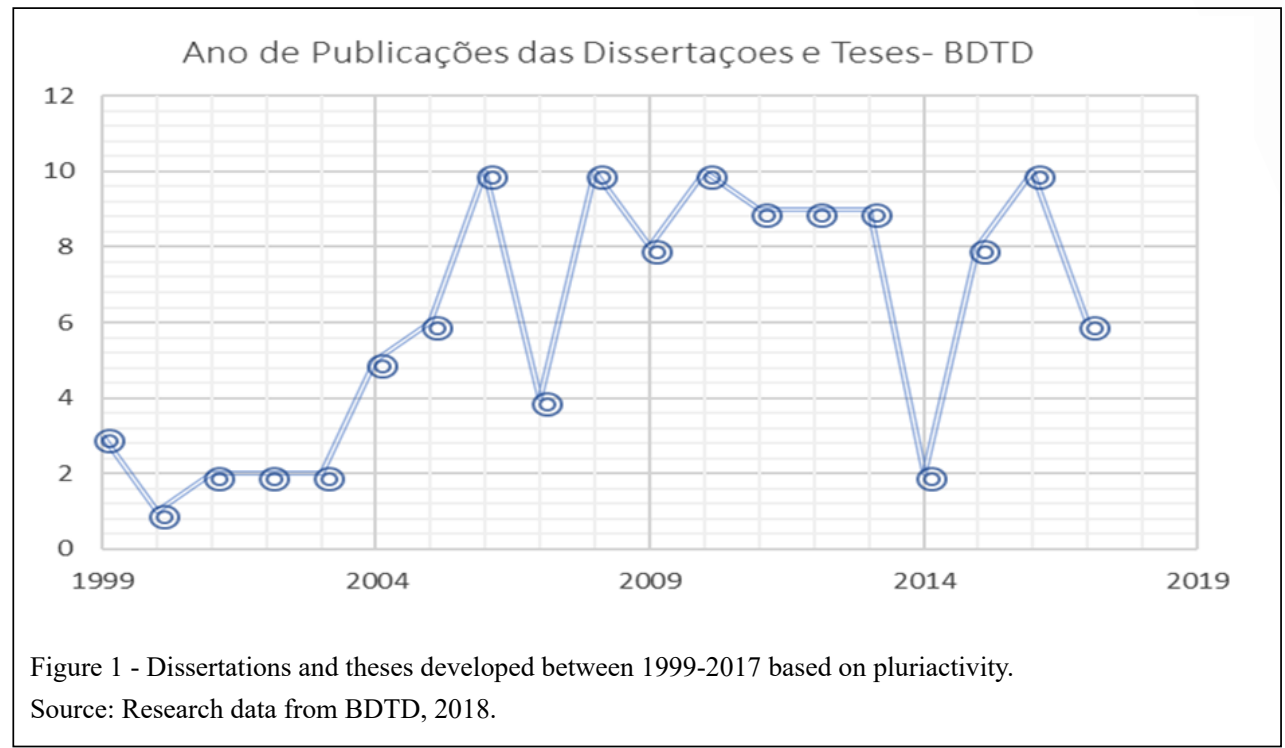

to each other, have different degrees of closeness. By observing the results of the HDC expressed in figure 2, Class 1 and Class 3 were classified as subdivisions of Class 2, in which the works on "pluriactivity" appeared strongly associated with the thematic of "Market and Work/Labor". Class 1 was divided into the "Reproduction and Survival Strategies" of farmer families. However, Class 3 does not reveal an aspect related to the content of theses and dissertations, but to the methodologies used in those documents. Therefore, Class 3 was not a priority for analysis in this study.

Class 2, designated as "Market and Work/ Labor", is the most important of the three classes, since it originated from the other two classes, corresponding to $36 \%$ of the corpus - that is, texts related to the dissertations and the theses analyzed. The words that contributed to the discussion of this class were: "production", "agriculture", "insertion", "families", "agricultural activities", "activities" and "market", highlighting above all the fact that pluriactivity appears as an analytical category related to the new alternatives of income and occupation within the territory in which the families of farmers live. The economic dynamism of the territory was evidenced as a fundamental factor for the development of pluriactivity. The dissertations and theses that compose the corpus analyzed highlighted the process of change that would affect the labor world and production in rural societies and, consequently, affecting the social organization of rural families. Sections transcribed below were taken from the dissertations and theses that composed the analyzed corpus and illustrate this result.

(...) "on the other hand the rural environment is receiving new functions and occupations and can no longer be seen only as a place where agricultural mineral goods or cheap labor is produced (...)". (Abstract 7).

(...) "with the transformations of the rural territories that assume features not essentially linked only with agricultural production but, expanding their spatial functions of leisure dwelling (...)". (Abstract 94)

(...) "the emergence of the market economy has altered the social context of agriculture mainly in the ways that work, and production were organized (...)". (Abstract 79)

Another point of the studies that were grouped in Class 2, "Market and Work/Labor", concerns the relationship of family's phenomenon. The researches associated with this class sought to understand the importance of pluriactivity for the social reproduction of the family unit, evidencing the new context of approach between the countryside and the city as generator of a field of possibilities for the family farmers to diversify the family income aiming their social reproduction (TERNOSKI, 2013; PONTE, 2004). Thus, the studies of this class place the analytical emphasis on the family rather than on the productive unit, indirectly showing a shift from the analytical focus of 'agriculture' to a pluralized rural with new socioproductive dynamics (VIRGOLIN, 2012; ROHNELT, 2011).

(...) "in social reproduction of the family unit which combines agricultural and non-agricultural activities 


\begin{tabular}{|c|c|c|c|c|c|}
\hline $\begin{array}{l}\text { CLASS 1: } \\
\mathbf{4 7 . 5 \%} \\
\text { Reproduction and } \\
\text { Strategies }\end{array}$ & Survival & \multicolumn{2}{|c|}{$\begin{array}{l}\text { CLASS 3: } \\
\mathbf{1 6 . 4 \%} \\
\text { Research Methodology }\end{array}$} & \multicolumn{2}{|l|}{$\begin{array}{l}\text { CLASS 2: } \\
36.1 \% \\
\text { Market and Work/Labor }\end{array}$} \\
\hline $\begin{array}{l}\text { Word/ } \\
\text { attribute }\end{array}$ & $\chi^{2}$ & $\begin{array}{l}\text { Word/ } \\
\text { atribute }\end{array}$ & $\chi^{2}$ & $\begin{array}{l}\text { Word/ } \\
\text { attribute }\end{array}$ & $\chi^{2}$ \\
\hline analyzes & 49 & data & 107 & production & 27 \\
\hline goal & 27 & qualitative & 60 & agriculture & 26 \\
\hline family farming & 21 & methodology & 51 & insertion & 23 \\
\hline construction & 18 & accomplish & 50 & families & 22 \\
\hline look for & 16 & data survey & 44 & agricultural activities & 21 \\
\hline development & 15 & survey & 41 & activity & 20 \\
\hline decade & 12 & information & 40 & market & 20 \\
\hline dissertation & 12 & interviews & 40 & income & 18 \\
\hline formation & 11 & application & 39 & growth & 18 \\
\hline county & 11 & search & 36 & countryside & 17 \\
\hline thesis & 10 & production & 35 & demonstrate & 16 \\
\hline elemento & 10 & $\begin{array}{l}\text { semi-structured } \\
\text { interview }\end{array}$ & 34 & affirm & 16 \\
\hline & & case study & 31 & non-agricultural activities & 16 \\
\hline
\end{tabular}

Figure 2 - Dendrogram of Hierarchical Descending Classification (HDC) obtained from the data of BDTD. The $\mathrm{X}^{2}$ of the words presented in each of the classes corresponded to a degree of significance of the word with the class of $<0.0001$.

Source: Research data, 2018.

characterizing the existence of pluriactivity in the context of peasant family farming (...)". (Abstract 41) (...) "this phenomenon consists of individuals from families living in the rural environment combine the exercise of one or more economic activities besides agriculture (...)". (Abstract 44)

Regarding Class 1, referring to the "Reproduction and Survival Strategies", which represented $47 \%$ of the corpus, it presents a clear complementarity in relation to Class 2, "Market and Work". For this reason, it has been classified in a subdivision of Class 2 . The words highlighted by the IRAMUTEQ software in this class also point to the characterization of pluriactivity as an alternative of income generation, geared toward the search for its social reproduction. The sections transcribed below were taken from the dissertations and theses that composed the analyzed corpus and illustrate this result. (...) "one of the transformations occurred refers to the development of pluriactivity and the diversification of the sources of income of rural families, with emphasis on those obtained without agricultural linkage (...)". (Abstract 36).
(...) "this work deals with the reproduction strategies of family farming in the municipality of David Canabarro and of the Alto Taquari microregion (...)". (Abstract 25)

(...) "the transformations of family farming and to what extent this process brings repercussions and or influences the dynamics of rural development and formation of styles of family farming (...)" (Abstract 58).

Among the works highlighted in Class 1, the work developed by FRANÇA (2016), which deals with the analysis of pluriactivity from the practices of economic, social and environmental sustainability. In this case, pluriactivity is understood by the author as the strategy adopted by the families for the generation of income. SOUSA (2006) studied pluriactivity as an alternative for survival or as new social reproduction strategies for family farmers in the region of Minas Gerais. FARIAS (2016) also worked on pluriactivity in the constitution of family farmers' incomes and their implications for family diversification, autonomy and social reproduction. Finally, the IRAMUTEQ software identified that these works presented the focus of their analysis 
on the non-agricultural activities developed by the members of the farmers' families.

\section{CONCLUSION}

The present research aimed to identify the interpretive tendencies related to the pluriactivity category that are gaining traction in the Brazilian academic field. The research used the database of the BDTD, analyzing the influence of the classic conceptions of pluriactivity in the academic scope. In the research, existence of interpretive divergences about the characteristics associated to the term "pluriactivity" was reported, present in the scientific literature since its origin. Such divergences among the classics of literature were basically related to the interpretation of pluriactivity as a contemporary phenomenon, restricted to regions characterized by diffuse industrialization; or, in contrast, as a phenomenon already existing in the past, marked by the simple combination of agricultural activities with para-agricultural and/or non-agricultural activities.

The limitations of this research are related to the difficulty of identifying the works that have become a reference in the study of pluriactivity. To be able to perceive the recurrence of citations of the same author over the decades in a significant number of works on the subject was not a laborious task. This preoccupation with the classification of the authors that became reference on the subject was considered important, due to being able to serve as reference to follow the affiliation of the conceptions adopted. Although, the dissertations and theses analyzed clearly pointed to the relevance of the dynamic economic context, for the occurrence of pluriactivity it was verified in the dissertations and theses analyzed in the period between 1999 and 2017, that the pluriactivity was predominantly interpreted as being associated with the precariousness of the conditions of survival of the farmers, being; therefore, understood as a strategy of reproduction of the family units. Thus, the context was not a determining factor for the understanding of the phenomenon. Only in a secondary way was pluriactivity interpreted in the dissertations and theses consulted, as the combination of agricultural and non-agricultural activities in regional contexts marked by the intersectorialization of the economy. Theses and dissertations analyzed showed, in this sense, the approximation of the labor market between the countryside and the city as a phenomenon characteristic of pluriactivity.

A positive aspected report in the works analyzed was the diversification of the contexts studied, such as environments already marked by tourism practices, such as studies carried out in rural communities and in settlements. It was also observed how the topic of pluriactivity was associated with the discussions related to rural development and sustainability issues, focusing therefore in current subjects. Pluriactivity has thus become an analytical category that portrays the strategies of social reproduction of families in contexts characterized by economic diversification, highlighting both strategies marked by feedback from non-agricultural income in agriculture, and those aiming to ensure the reproduction of the family group.

\section{ACKNOWLEDGEMENTS}

Authors thank the Conselho Nacional de Desenvolvimento Científico e Tecnológico (CNPq) for providing scholarship (\#130501/2015-8), the Coordenação de Aperfeiçoamento de Pessoal de Nível Superior (CAPES), and the Centro de Ciencias Agrárias of the Universidade Federal de Viçosa (UFV) for the financial support.

\section{DECLARATION OF CONFLICT OF} INTERESTS

The authors declare no conflict of interest. The founding sponsors had no role in the design of the study; in the collection, analyses, or interpretation of data; in the writing of the manuscript, and in the decision to publish the results.

\section{AUTHORS' CONTRIBUTIONS}

All authors contributed equally for the conception and writing of the manuscript. All authors critically revised the manuscript and approved of the final version.

\section{REFERENCES}

Biblioteca Digital Brasileira de Teses e Dissertações -BDTD. [Online]. Available from: <http://bdtd.ibict.br/vufind/>. Accessed: Jun. 18, 2018.

BLAD, M. Pluriactivity of farming families-old phenomenon in new times. In: European Rural Development Network Studies. Rural Areas and Development., p.155-165, v.7, 2010. Available from: <https://ideas.repec.org/a/ags/erdnra/139799. html>. Accessed: Jun. 16, 2018.

BOUCHAKOUR, R.; BEDRANI, S.,Pluriactivity, the Dutch disease and sustainable agriculture in Algeria. International Journal of Technology Management and Sustainable Development, v.14 n.3. 2015. Available from: <https://www.ingentaconnect. com/content/intellect/tmsd/2015/00000014/00000003/art00005>. Accessed: Jun. 23, 2018.

CAMPAGNE, E.; et al. Three Agricultural Regions of France: Three Types of Pluriactivity. Journal of Rural Studies, 1990 vol.6 $\mathrm{n}^{\circ} 4 \mathrm{pp} .415-422$. Available from: $<$ https://www.sciencedirect.com/ science/article/pii/074301679090055D>. Accessed: Jun. 24, 2018. 
CARNEIRO,M. J. Camponeses, agricultores e pluriatividade. Rio de Janeiro: Contracapa, 1998.

Pluriatividade da agricultura no Brasil: uma reflexão crítica. In: SCHNEIDER, S. (Org). A diversidade da agricultura familiar. Porto Alegre, RS: UFRGS, $1^{\mathrm{a} e}$ edição. 2006.

CARNEIRO, M. J. Pluriatividade da agricultura no Brasil: uma reflexão crítica. In: SCHNEIDER, S. (Coord.). A diversidade da agricultura familiar. Série Estudos Rurais. Porto Alegre: Editora da UFRGS, 2ª edição. 2009.

CARNEIRO, M. J.; PALM, J. L. Modos de vida de agricultores familiares de montanha: um estudo de caso em São Pedro da Serra - Nova Friburgo - RJ. Revista Iluminuras,(online) Porto Alegre, v.17, n.41, p.180-202, jan. - jun., 2016. Available from: $<$ https://seer.ufrgs.br/iluminuras/article/viewFile/64566/37345>. Accessed: Jul. 5, 2018

CHASE, J. The place of pluriactivity in Brazil's agrarian reform institutions. Journal of Rural Studies. 2010. n ${ }^{\circ} 26$ pp.85-93. Available from: <https://www.sciencedirect.com/science/article/ pii/S0743016709000461>. Accessed: Jul. 9, 2018.

DEL GROSSI, M.E. Evolução das ocupações não-agrícolas no meio rural brasileiro: 1981-1995. 1999. Tese (Doutorado) - Instituto de Economia da Unicamp, Campinas, 1999. Available from: <http://repositorio.unicamp.br/jspui/handle/ REPOSIP/285428>. Accessed: Jul. 10, 2018.

ESCHER, F. et al. Caracterização da Pluriatividade e dos Plurirrendimentos da Agricultura Brasileira a partir do Censo Agropecuário. Revista de Economia \& Sociologia Rural, Piracicaba, v.52, n.04, p.643-668, dez. 2014. Available from: $<$ http://www.scielo.br/scielo.php?script=sci arttext\&pid $=$ S0103-20032014000400002>. Accessed: Jul. 12, 2018.

FARIAS, A. C. Estratégias de reprodução social da agricultura familiar: A pluriatividade no município de Assunção - PB. 2016. 115p. Dissertação (Mestrado em Desenvolvimento Regional) Universidade Estadual da Paraíba- PB. Available from: $<$ http://tede. bc.uepb.edu.br/jspui/handle/tede/2621>. Accessed: Jul. 18, 2018.

FRANÇA, J. A. O. A pluriatividade na sustentabilidade socioambiental do Parque Laranjeira em Juína/MT. 2016. 78p. Dissertação (Mestrado em Ambiente e Desenvolvimento), Centro Universitário UNIVATES, Lajeado, 28 Jun. 2016. Available from: $<$ https://www.univates.br/bdu/bitstream/10737/1132/1/2016Joao AparecidoOrtizdeFran\%C3\%A7a.pdf>. Accessed: Jul. 19, 2018.

FULLER, A.M. Part-time farming: the enigmas and the realities. In Research in Rural Sociology and Development. Volume 1: Focus on Agriculture, Schwarzweller, H. (ed.). Jair Press, Greenwich, Connecticut. 1984.

FULLER, A. M. From part-time farming to pluriactivity: a decade of change in rural Europe. Journal of Rural Studies. N.6 (4), pp.361-373.1990. Available from: <https://www. sciencedirect.com/science/article/pii/074301679090049E >. Accessed: Jul. 20, 2018.

GRAZIANO DA SILVA, J. A nova dinâmica da agricultura brasileira. Campinas: UNICAMP, 1996.

GRAZIANO DA SILVA, J. O novo rural brasileiro. Nova Economia, Belo Horizonte, v. 7, n. 1, p. 43-82, maio. 1997.
GRAZIANO DA SILVA, J. O novo rural brasileiro. Campinas, UNICAMP, Instituto de Economia, (Coleção Pesquisas, 1), 1999.

GRAZIANO DA SILVA, J. F; CAMPANHOLA, C. Desenvolvimento Local e a Democratização dos Espaços Rurais. Cadernos de Ciência e Tecnologia, Brasilia, v17, n.1, p11-4-, jan/ abril. 2000. Available from: <https://seer.sct.embrapa.br/index. php/cct/article/download/.../4986>. Accessed: Jul. 20, 2018.

GRAZIANO da S. J. \& EDUARDO Del G. M. Rural Nonfarm Employment and Incomes in Brazil: Patterns and Evolution. World Development, Elsevier, vol. 29(3), pages 443-453, March. 2001 Available from: <https://ideas.repec.org/a/eee/wdevel/ v29y2001i3p443-453.html>. Accessed: Jul. 20, 2018.

KAGEYAMA, A. Pluriatividade na agricultura: alguns aspectos conceituais. In. Encontro Brasileiro de Economia E Sociologia Rural, XXXVI, 1998, Poços de Caldas. Anais...Poços de Caldas: SOBER, v.2, p.555-556. 1998.

Desenvolvimento rural: conceitos e aplicações ao caso brasileiro. Rio Grande do Sul: Editora da UFRGS, 2008.

KAUTSKY, K. A questão agrária. Portugal: Proposta, 1980.

LOUGHREY, J.; et al. The Role of Pluriactivity in Farm Exit and Labour Supply Decisions. Factor Markets Working Paper No. 67, Centre for European Policy Studies, Brussels. 2013.

MACHADO, A. M. B.; CASALINHO, H. D. Crítica à pluriatividade e suas relações com o campesinato e a reforma agrária. Revista Nera, ano 13, n.17, 2010. Online. Available from: $<$ http://revista.fct.unesp.br/index.php/nera/article/view/1352>. Accessed: Jul. 20, 2018.

MATTEI, L. F. Pluriatividade e desenvolvimento rural no Estado de Santa Catarina. Campinas. Tese de Doutorado. (Doutorado no Instituto de Economia da Universidade Estadual de Campinas). 1999.

NASCIMENTO, C. A. Pluriatividade, pobreza rural e políticas públicas. Tese (Doutoramento)- Instituto de Economia, Universidade Estadual de Campinas, Unicamp, 2005. Ab Available from: <http://repositorio.unicamp.br/jspui/handle/ REPOSIP/285541>. Accessed: Jun. 21, 2018.

A pluriatividade das famílias rurais no Nordeste e no Sul do Brasil: pobreza rural e políticas públicas. Economia e Sociedade. Ago 2009, vol.18, no.2, p.317-348. ISSN 0104-0618. Available from: <http://www.scielo.br/pdf/ecos/v18n2/a04v18n2. pdf $>$. Accessed: Jun. 22, 2018.

NIEMELA, T.; HAKKINEN, R., The Role of Pluriactivity for Continuity and Survival in Family Farm Firms. Journal of Entrepreneurship, Management and Innovation, Vol. 10, Issue 4, 2014, pp. 7. March 15, 2015. Available from: <https://papers. ssrn.com/sol3/papers.cfm?abstract_id $=2578695>$. Accessed: Jun. 23,2018

RATINAUD, P. IRAMUTEQ: Interface de R pour les Analyses Multidimensionnelles de Textes et de Questionnaires. 2009. [Computer software]. Available from: <http://www. iramuteq.orghttp://lexicometrica.univ-paris 3.fr/jadt/jadt2012/ Communications/Ratinaud,\%20Pierre\%20et\%20al.\%20-\%20 Application $\% 20$ de $\% 201 a \% 20$ methode $\% 20$ Alceste.pdf $>$. Accessed: Jun. 25, 2018. 
RATINAUD, P., \& MARCHAND, P. Application de la méthode ALCESTE à de "gros" corpus et stabilité des "mondes lexicaux": analyse du "CableGate" avec IraMuTeQ. Em: Actes des 11 eme Journées internationales d'Analyse statistique 35 des Données Textuelles (835-844). Presented at the 11eme Journées internationales d'Analyse statistique des Données Textuelles. JADT 2012, Liège. Available from: < http://lexicometrica.univparis3.fr/jadt/jadt2012/Communications/Ratinaud,\%20Pierre $\% 20$ et $\% 20$ al. $\% 20-\% 20$ Application $\% 20$ de $\% 201 \mathrm{a} \% 20$ methode $\% 20$ Alceste.pdf $>$ Accessed: Jun. 28, 2018.

SACCO DOS ANJOS, F. Agricultura familiar, pluriatividade e desenvolvimento rural no Sul do Brasil. Pelotas: EGUFPEL, 2003.

SCHNEIDER, S. O desenvolvimento agrícola e as transformações da estrutura agrária nos países do capitalismo avançado: a pluriatividade. Revista Reforma Agrária, Campinas/SP, n. 24, v.3, set/dez. p. 106-132. 1994.

Agricultura familiar e Industrialização. Porto Alegre, Ed.UFRGS, $2^{\text {a }}$ Edição, 1999.

A pluriatividade na Agricultura familiar. Porto Alegre. Editora da UFRGS, 359p. 2003.

SCHNEIDER, S. A PLURIATIVIDADE NO BRASIL: proposta de tipologia e sugestao de políticas. $44^{\circ}$ Congresso da Sociedade Brasileira de Economia, Administracao e Sociologia Rural (SOBER), Julho 23-27, 2006, Fortaleza, Ceará, Brasil. 2006. Available from: <https://ageconsearch.umn.edu/record/145064/ files/193.pdf>. Accessed: Jun. 19, 2018.

SOUSA, J. F. Resignificando antigas práticas: As atividades não agrícolas como estratégias de sobrevivência dos agricultores familiares no Município de Santa Maria do Suaçuí, Minas Gerais. Centro Universitário de Caratinga-UNEC: Dissertacao (Mestrado em Meio Ambiente e Sustentabilidade), 2006. Available from: <http://livros01.livrosgratis.com.br/cp023778. pdf $>$. Accessed: Jun. 21, 2018.

TEIXEIRA, V. L. Novos contornos ocupacionais no meio rural fluminense: um estudo sobre a pluriatividade entre agricultores familiares. 2009. 263p. Tese (Doutorado em Economia Aplicada) - Instituto de Economia, Universidade Estadual de Campinas-SP. 2009. Available from: $<$ http://repositorio.unicamp.br/jspui/handle/ REPOSIP/285692>. Accessed: Jun. 21, 2018.

TERNOSKI. S. Estratégias de melhoria da renda da agricultura familiar: análise a partir da base social da CRESOL/ Prudentópolis. Dissertação (Mestrado em Desenvolvimento Regional) - Programa de Pós-Graduação em Desenvolvimento Regional. Universidade Tecnológica Federal do Paraná - UTFPR. Pato Branco, 2013. Available from: $<$ http://repositorio.utfpr.edu. br/jspui/bitstream/1/629/1/PB PPGDR M Ternoski\%2C\%20 Sim\%C3\%A3o_2013.pdf.pdf $>$. Accessed: Jun. 21, 2018.

VIRGOLIN, I. W. C. O sentido do trabalho pluriativo para os agricultores familiares: um estudo á partir da cooperativa de recicladores orgânicos e inorgânicos de Santa Cecília do Sul/RS. 2012. 134 p. Dissertação (Mestrado em Extensão Rural)-Universidade Federal de Santa Maria, RS, 2012. Available from: <https://repositorio.ufsm.br/handle/1/8874>. Accessed: Jun. 25, 2018.

WANDERLEY, M. N. B. O mundo rural brasileiro: acesso a bens e serviços e integração campo-cidade. Estudos Sociologia e Agricultura, Rio de Janeiro, vol.17, n.1, 2009, p. 60-85. Online. Available from: <http://r1.ufrrj.br/esa/V2/ojs/index.php/esa/ article/view/308/304>. Accessed: Jun. 27, 2018. 